\title{
Root Canal Anatomy Visualization using Three-Dimensional Computed- Tomography and Transparent Preparation
}

\author{
Alexey V. Silin, Irina V. Pyatkova \\ Department of General Dentistry, North-West State Medical University II Mechnikov, Mechnikov, Saint- \\ Petersburg 195067, Russia \\ Correspondence e-mail to: pyatkova.irina@gmail.com
}

\begin{abstract}
Three-dimensional Computed Tomography (CT) is used to analyze the topography of the root canal anatomy in order to make a decision in choosing root canal preparation method. There is a method that make extracted teeth transparent maintaining its anatomical shape and size. It is important to compare the accuracy of the two visualization methods. Objective: To compare the transmission accuracy of root canals anatomy by two visualization methods, three-dimensional CT and transparent tooth preparation. Methods: Mandibular third molar was used as sample. The three-dimensional CT scan was performed before extracting the teeth. Then teeth were extracted and placed in solutions that made them transparent. Results: Despite the fact that the character of dental origin in terms of the angle of the crown, the curvature of the crown, the deviation of the root showed in three-dimensional CT, other tooth anatomical parameters were equally well detected using a transparent tooth preparation. Overall, the curvature of the root canals is more clearly shown by transparent tooth preparation. Conclusion: Transparent tooth preparation provides superior visualization of real root canal anatomy compared to three-dimensional CT, however the later could give us more information about the relation of the tooth within the jaw.
\end{abstract}

\begin{abstract}
ABSTRAK
Visualisasi anatomi saluran akar menggunakan computed tomography tiga dimensi dan preparasi transparan. Computed Tomography (CT) tiga dimensi sedang dikembangkan agar dapat digunakan untuk menganalisis topografi anatomi saluran akar untuk membuat keputusan tentang metode preparasi yang tepat. Analisis bentuk dan ukuran anatomi gigi juga dapat dilakukan menggunakan metode transparan. Penting untuk membandingkan ketepatan hasil analisis dari kedua metode tersebut. Tujuan: Membandingkan akurasi analisis anatomi saluran akar dengan dua metode CT tiga dimensi dan preparasi transparan. Metode: Gigi molar tiga bawah digunakan sebagai sampel analisis. Analisis dengan CT tiga dimensi dilakukan sebelum gigi diekstraksi. Gigi yang selanjutnya diekstraksi tersebut kemudian diolah untuk mendapatkan sediaan transparan. Hasil: Walaupun karakteristik gigi yang berhubungan dengan sudut kemiring mahkota, bentuk kurva mahkota dan devisasi saluran akar dapat terlihat melalui analisis dengan CT tiga dimensi, parameter anatomi gigi yang lain dapat diperlihatkan melalui sediaan transparan. Sediaan transparan dapat memperlihatkan kurva saluran akar secara lebih jelas. Simpulan: Analisis sediaan transparan dapat memberikan gambaran anatomi saluran akar yang sangat jelas dan lebih baik daripada CT tiga dimensi. Analisis dengan CT tiga dimensi dapat memberikan informasi tambahan tentang hubungan gigi di dalam rahang.
\end{abstract}

Key words: computed tomography, root canal anatomy, three-dimensional imaging, transparent tooth preparation

\section{INTRODUCTION}

A detailed understanding of the root canals, their shape and the number is the foundation of endodontics. ${ }^{1}$ Features of the structure of the root canal are needed by dental practitioner when performing endodontic treatment. Attempts to gather possible configuration about root canal have been performed, but conflicting information about the structure of the root canal is still present. It is caused by the fact that each tooth might have unique configuration. ${ }^{2,3}$ The anatomical features of the tooth root canal would influence the type of endodontic instruments used. ${ }^{4}$ Radiographs, which are more than a century helps physicians in endodontic therapy, are two-dimensional and do not give complete 
information about the cavity of the tooth. ${ }^{5}$ In recent years, dental computed tomography is used for the examination of patients with pathology of the teeth and jaws. ${ }^{6}$ By obtaining three-dimensional digital image of the tooth, it is possible to view the tooth from three projections and significantly enhances diagnosis in endodontics. ${ }^{7}$ Despite the emergence of new technologies and improvement of facilities, the question of endodontic treatment quality remains important. There is a high risk of instruments breakage in curved root canals. Therefore it is important to find out how exactly 3D KT transmits anatomy, is it possible to use this method to reduce the number of complications in the root canals treatment.

In order to visualize the anatomical features of root canal of a tooth, we have developed a method of transparent tooth preparation on extracted tooth, which allows to get a visual three-dimensional image of the entire root canal system while maintaining the total volume of the dentine of the tooth. This invention is registered for patent No. 2373582 dated November 20, $2009 .{ }^{8}$ The question of endodontic treatment quality remains important-there is a high risk of instruments breakage in curved root canals. The purpose of the study was to compare the transmission accuracy of root canals anatomy by two visualization methods-threedimensional CT and transparent tooth preparation.

\section{METHODS}

A lower right third molar was chosen as one of the teeth being studied. The patient underwent removal of the 48 was asked to participate voluntarily in the study and a written informed consent form was granted. A three-dimensional dental CT was performed using i-Cat Vision (CT Dent Ltd, UK) according to manual instruction. The i-Cat scanner is specially designed for dental use and its technology is known as Cone Beam CT (CBCT). CT scan uses multiple small bursts of radiation, dispersed from various angles toward the target area, rendering detail images from different angles on film. Patients were asked to remove all metallic items before beginning, including eyeglasses. Patients were asked to remove any dentures. Lead aprons were provided to help protect the patient's internal organs from the radiation exposure.

The tooth was then extracted and cleaned. The endodontic access was subsequently created (Figure 1B). The tooth was treated by a procedure which allows to make the extracted tooth transparent. The patent for transparent tooth preparation is No. 2373582 of November 20, 2009. ${ }^{8}$ The method included tooth storage in sodium hypochlorite solution. This step would cause oxidation and hydrolysis of organic compounds - proteins (including the key enzymes of cells), as well as osmotically draw fluid from the cells, resulted in increased in tooth porosity (Figure 1A). ${ }^{9,10}$
Furthermore, the tooth was placed in an acid solution in order to dissolve enamel and to cause dentin demineralization. This method would process the tooth in its entirety and would maintain dentin, so that minimize changes in the structure of the tooth root canals. After demineralization the tooth was placed in an alcohol solution for the dehydration.

To complete the process necessary to create a transparent tooth preparation was impregnating the sample with a solution, which was an aromatic organic compound derived from benzene. Due to the fact that this solution has a refractive index was close to

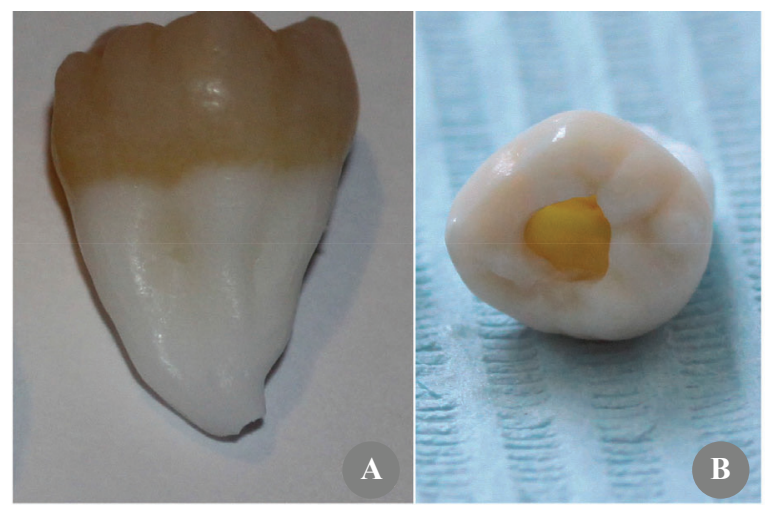

Figure 1. Initial steps of transparent tooth preparation. A: after the tooth was treated with sodium hypochloride; B: endodontic access was performed.
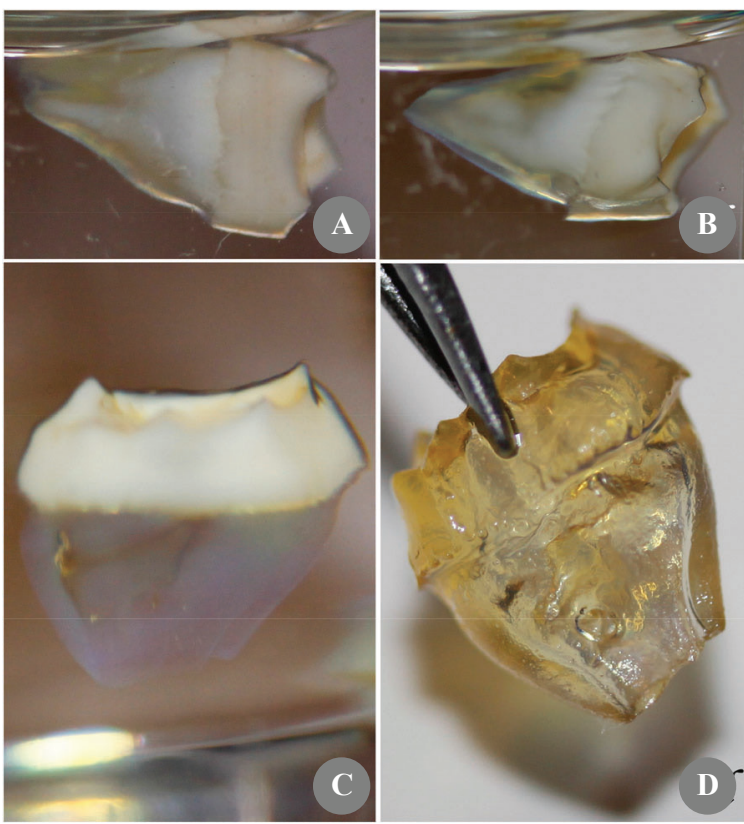

Figure 2. Steps of transparent tooth preparation. A: the tooth was treated with a solution for five minutes, after which marked changes in transparency, the outer surface of the root; B: showed a tooth that was in the solution for 30 minutes, an increase in the degree of transparency; C: showed the resulting clear product of the tooth, the pulp inside the tooth was visible. Exposure of a tooth in the solution was one hour; D: showed a clear product of the tooth in the air, which was capable of for a long time to maintain its transparency. 
the refractive index of the dentin organic matrix, the tooth would become transparent. Figure 2 showed the process of increasing the transparency of the tooth, which began as impregnating tooth solution. To identify the structural features of the root canals of the extracted tooth, together with the methodology of the visualization was made tooth tissues coloring with water-soluble dye. The dye bound to dentin proteins (Figure 3).

\section{RESULTS}

The three-dimensional dental CT allowed estimation of the location of the 48 with respect to its bony structures, and other teeth in the lateral projection. ${ }^{11}$ Figure 4 showed the location of 48 from buccal view. Computer diagnostics revealed intra-osseous location, shape, size and structure of the tooth with a high accuracy, as well as a cross-sectional images of the longitudinal section of the tooth crown and root of 48, which indicates the presence of two root canals in Figure 5C.

On a transparent preparation of the tooth it is clear that pulp cavity has a greater volume than what is seen on CT (Figure 3). Two thin and curved root canals were seen in the 48 using three-dimensional $\mathrm{CT}$ and transparent tooth preparation. Application of the developed technique allowing three-dimensional visual imaging of the entire root canal system while maintaining the total volume of the dentine of the tooth. The apical portion of the tooth, through colored dye is clearly visible (Figure 3), the tip of the tooth is not formed, is similar to slit-like structure.

\section{DISCUSSION}

Three-dimensional computed tomography allows accurate diagnosis to determine the localization features of the teeth relative to other anatomical structures in the maxillofacial region as well as knowing the presence and severity of inflammation in the periapical region. This visualization would optimize the evaluation of the tooth therefore helps preparation of instruments and as well as reducing the risk for both endodontic and prosthetic treatment failure.

The method of computed tomography can realistically assess the amount of roots, root canals, the degree of curvature of the root, as well as spliced roots. At the same time during the study we found that the degree of curvature of the root canals are not always clearly visible on CT 3D, there is uncertainty due to the large resolution to clarify the course of the root canal. On a transparent remote preparation of the tooth is possible to estimate the true degree of curvature of the root canal because of the visualization.
The results of the two methods are compared visually. Comparison of several criterias of the tooth using images on CT and transparent tooth preparation summarized in Table 1. The criterias include number of roots, number of root canals, the degree of curvature of the root, the degree of curvature of the root canal, finger-joined roots, the outer surface of the relief, the angle of the crown, the curvature of the crown, the deviation of the root, with respect to the localization of anatomical structures.

In Figure 5C on 3D CT, we define the presence of two root canals. However, additional information about the curvature of the root which forming a S-shaped form in the medial root and the presence of another curvature in the two-third of the root was showed in transparent tooth preparation.

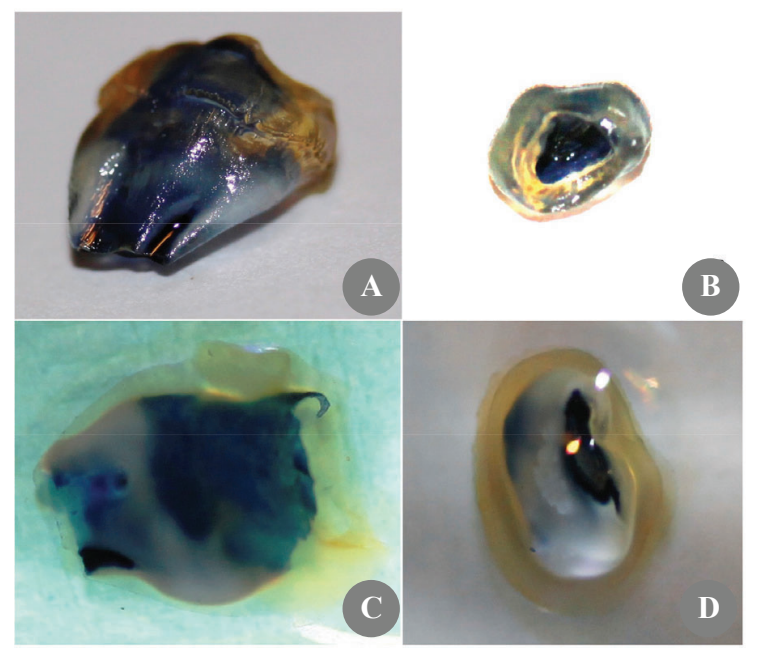

Figure 3. Introduction of dyes after transparent tooth preparation. A: after dye introduction resulting the outer surface of the 48 relief; B: presence of two root canals which were connected with a wide isthmus; $C$ : after further processing of dyes, the tooth cavity and root canals were filled with blue-colored dye, dentin showed a yellowish with large amount of pulp chamber; D: the tip of the tooth has not been formed, showing a slit-like structure.

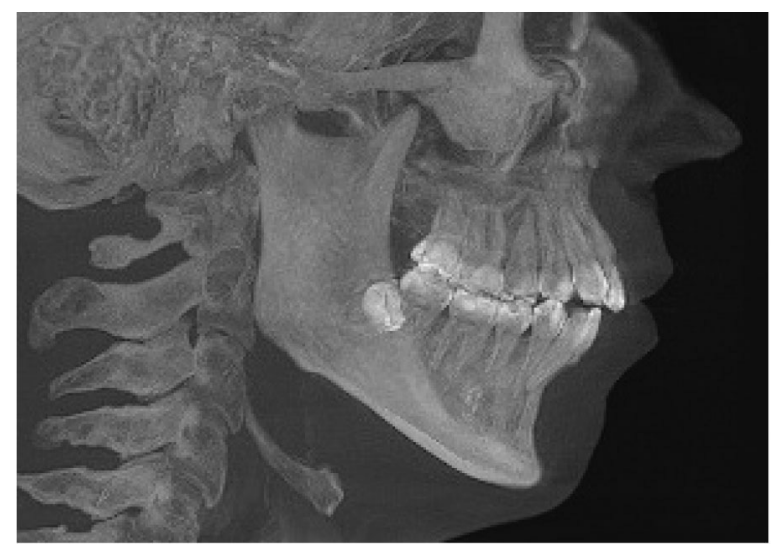

Figure 4. Three-dimensional CT of tooth 48 localization on transversal projection 


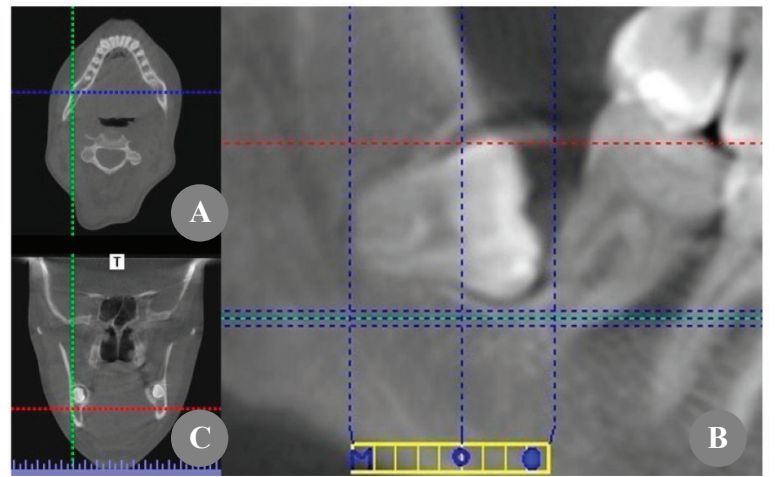

Figure 5. Three-dimensional CT of localization of impacted 48. A: sagital projection; B: frontal projection; C: transversal projection. The line that passes longitudinally through the middle of the crown and the tooth root, detects the presence of two root canals.

Table 1. Comparison of several tooth anatomical criterias using three-dimensional CT and transparent tooth preparation

\begin{tabular}{lcc}
\hline \multicolumn{1}{c}{ Anatomical criterias } & $\begin{array}{c}\text { Transparent } \\
\text { tooth } \\
\text { preparation }\end{array}$ & $\begin{array}{c}\text { Three- } \\
\text { dimensional } \\
\text { CT }\end{array}$ \\
\hline $\begin{array}{l}\text { The number of roots } \\
\text { The number of root canal }\end{array}$ & + & + \\
$\begin{array}{l}\text { The degree of curvature of } \\
\text { the root }\end{array}$ & + & + \\
$\begin{array}{l}\text { The degree of curvature of } \\
\text { the root canal }\end{array}$ & + & $+/-$ \\
$\begin{array}{l}\text { Spliced roots } \\
\text { The relief of the outer }\end{array}$ & + & + \\
surface & + & - \\
The angle of the crown & + & + \\
$\begin{array}{l}\text { The curvature of the } \\
\text { crown }\end{array}$ & + & + \\
The deviation of the root & + & + \\
$\begin{array}{l}\text { Localization with respect } \\
\text { to anatomical structures }\end{array}$ & - & + \\
\hline
\end{tabular}

This information is very useful when performing root canal treatment in the stage of instrumentation and technique preparation. Thus, choosing the proper imaging technique for root canal anatomy is very important to clarify the true structure of root canals, therefore helping in professional training and clarifying the true structure of root canals, therefore helping in professional training. ${ }^{12}$

Transparent preparation of the extracted teeth is indispensable as a visual aid for the high-level training in endodontics section. This method allows students to see the native structure of root canals, with apical Deltas and the isthmuses between the channels, additional channels and the curvature degree. Understanding the anatomy of root canals and optimizing their preparation by selecting the appropriate method of root canal treatment can improve the quality of endodontic treatment. $^{12}$

The quality of endodontic treatment of root canals remains actual. There are many methods of root canal treatment, the method chosen due to its anatomical features. ${ }^{12}$ If there is no accurate information about the degree of curvature of the root canal, in a case of complex anatomy the physician cannot be at a preliminary stage to choose a method of processing, which will significantly reduces the degree of complications of root canal preparation.

\section{CONCLUSION}

Transparent tooth preparation provides superior visualization of real root canal anatomy compared to three-dimensional CT, however the later could give us more information about the relation of the tooth within the jaw.

\section{REFERENCES}

1. Vertucci FJ. Root canal anatomy of the human teeth. Oral Surg Oral Med Oral Pathol. 1984;58: 589-99.

2. Vesheva YG. Expert analysis of errors and complications of endodontic treatment (medical and legal aspects). [dissertation]. Moscow, Moscow State Medico-stomatological University; 2005. Russian.

3. Rehachev VM, Byhovskaya OA, Matveeva LG. Errors in diagnosis of retreatment with canals that lead to claims on the quality of care. Endodontia Today. 2002;3:57-8. Russian.

4. Dubova MA, Shpak TA, Kornetova IV. Modern technology in endodontics. St-Petersburg 2005;36:624. Russian.

5. Barbosa FO, Gusman H, Pimenta de Arajo MC. A comparative study on the frequency, location, and direction of accessory canals filled with the hydraulic vertical condensation and continuous wave of condensation techniques. J Endod. 2009; 35:397-400.

6. Prokhvatilov GI, Shmidt TA. Using three-dimensional dental computerized tomography in the diagnosis and treatment of complications of dental caries. Bulletin of the Russian Military Medical Academy. 2010;2:114-5. Russian.

7. Paten information [Internet] [cited 2012 August 22]. Available from: http://bd.patent.su/23730002373999/pat/servl/servlet0c5b.html. Russian.

8. Batyukov NM, Chibisova MA, Kurganova IM. The study of the structural features of the teeth by dental computed tomography and selection of optimal methods of endodontic treatment. Clin Endo. 2007;1:54-64. 
9. Prokhvatilov GI, Shmidt TA. Using three-dimensional dental computerized tomography in the diagnosis and treatment of complications of dental caries. Bulletin of the Russian Military Medical Academy. 2010;2:114-5. Russian.

10. Ber R, Baumann M, Kim S. Atlas of Dentistry. Endodontology. Moscow. Medpress-inform. 2006; 68-78. Russian.
11. Paten information [Internet] [cited 2012 August 22]. Available from: http://bd.patent.su/23730002373999/pat/servl/servlet0c5b.html. Russian.

12. Batyukov NM, Chibisova MA, Kurganova IM. The study of the structural features of the teeth by dental computed tomography and selection of optimal methods of endodontic treatment. Clin Endo. 2007;1:54-64. 